\title{
Aberrant Patterns in the Strawberry Poison Frog, Oophaga pumilio (Schmidt 1857)
}

\author{
César L. Barrio-Amorós ${ }^{1}$, Barry Hovland ${ }^{2}$, Rosibel Barrantes ${ }^{3}$, Jefferson Brooks ${ }^{4}$, and Orlando Vargas ${ }^{5}$ \\ ${ }^{1}$ Doc Frog Expeditions, Uvita, Puntarenas, Costa Rica (cesarlba@yahoo.com) \\ ${ }^{2}$ Minneapolis, Minnesota 55416, USA \\ ${ }^{3}$ Amazilia Servicios Profesionales, San Francisco de Heredia, Costa Rica \\ ${ }^{4}$ Ellensburg, Washington 98926, USA \\ ${ }^{5}$ Organización para Estudios Tropicales-Estación Biológica La Selva, Heredia, Costa Rica
}

$T_{1}^{1}$ The Strawberry Poison Frog, Oophaga pumilio (Schmidt 1857), has the most variable coloration of any frog in the world (Walsh 1994; Lötters et al. 2007). van der Lingen and van der Lingen (2012) recorded 102 color morphs from throughout the species' range, which extends from eastern Nicaragua southward into western Panamá. Whether all of these exceedingly variable frogs should be assigned to the same species is unclear. Hagemann and Pröhl (2007) demonstrated the presence of three clades and suggested that they represent three species. One clade is comprised of the western populations, including all known variations in the area of Bocas del Toro, Panama. The second is comprised of populations from northwest of the Río Reventazón in Costa Rica and northward into Nicaragua, and the authors suggested that this clade could bear the name O. typographa (Keferstein 1867). Frogs composing the third clade, for which no existing name is available, are from Isla Escudo de Veraguas, Panama (see also comments in Frost 2016).

In general, color morphs in Costa Rican populations are less variable than those in Panama. Herein, however, we report four aberrant color patterns. Two from the northern clade (the proposed O. typographa clade) are both from the La Selva Biological Station in Heredia Province. Two others represent the western clade and are from Matina in Limón Province.

\section{La Selva}

The herpetofaunal assemblage of La Selva has been well studied (e.g., Savage 2002; Guyer and Donnelly 2005). The most abundant color pattern in the population at La Selva and in those generally from north of the Río Reventazón is the "blue jeans" morph, with a red head and body and marine blue limbs (Fig. 1A).

J. Brooks saw an unusual individual (Fig. 1B) at La Selva. This frog, which was photographed and released, had scattered black dots on the red anterior part of the body and the blue limb color extending well onto the posterior part of the body. The middorsal blue area and that on the hindlimbs was somewhat darker than on the flanks.

Guyer and Donnelly (2005) noted the presence of a blue frog but provided no further data. O. Vargas photographed that individual (Fig. 1C) on 17 September 1999 after it was captured by Brian Plaster and Jimmy Trejos, two primatolo-
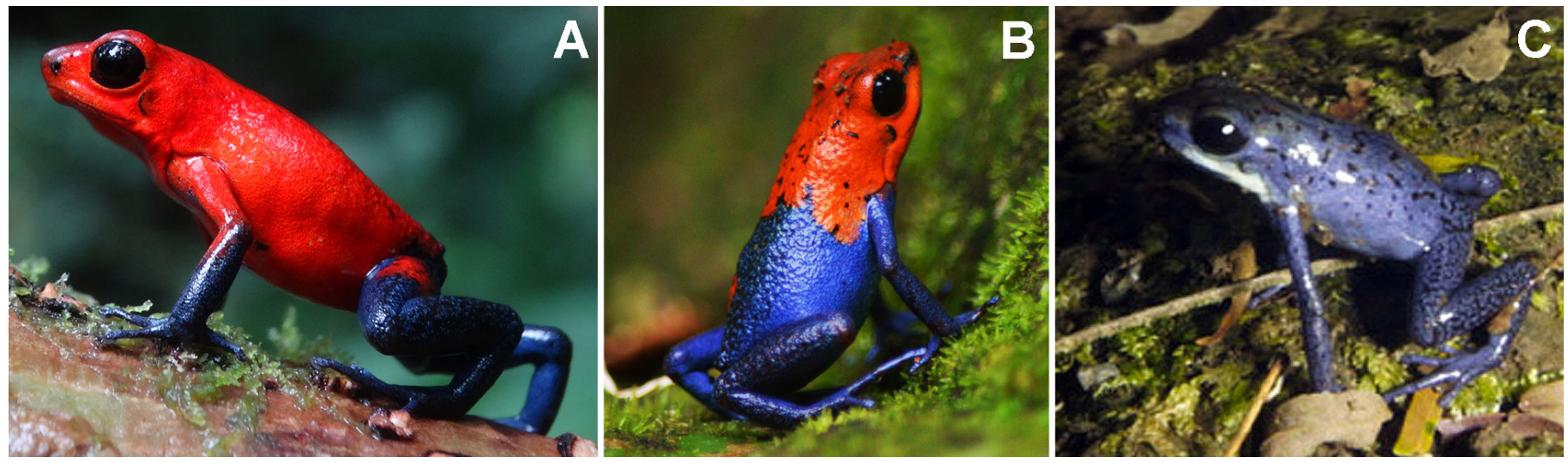

Fig. 1. Strawberry Poison Frogs (Oophaga pumilio) from north of the Río Reventazon; these are representatives of the northern clade (see text). (A) Typically colored morphs from north of the Río Reventazon; photograph by C. Barrio-Amorós. (B) An aberrant color pattern encountered at the La Selva Biological Station, Heredia Province, Costa Rica; photograph by J. Brooks. (C) An aberrant blue individual at La Selva; photograph by O. Vargas.

Copyright $($ 2017. César L. Barrio-Amorós. All rights reserved. 

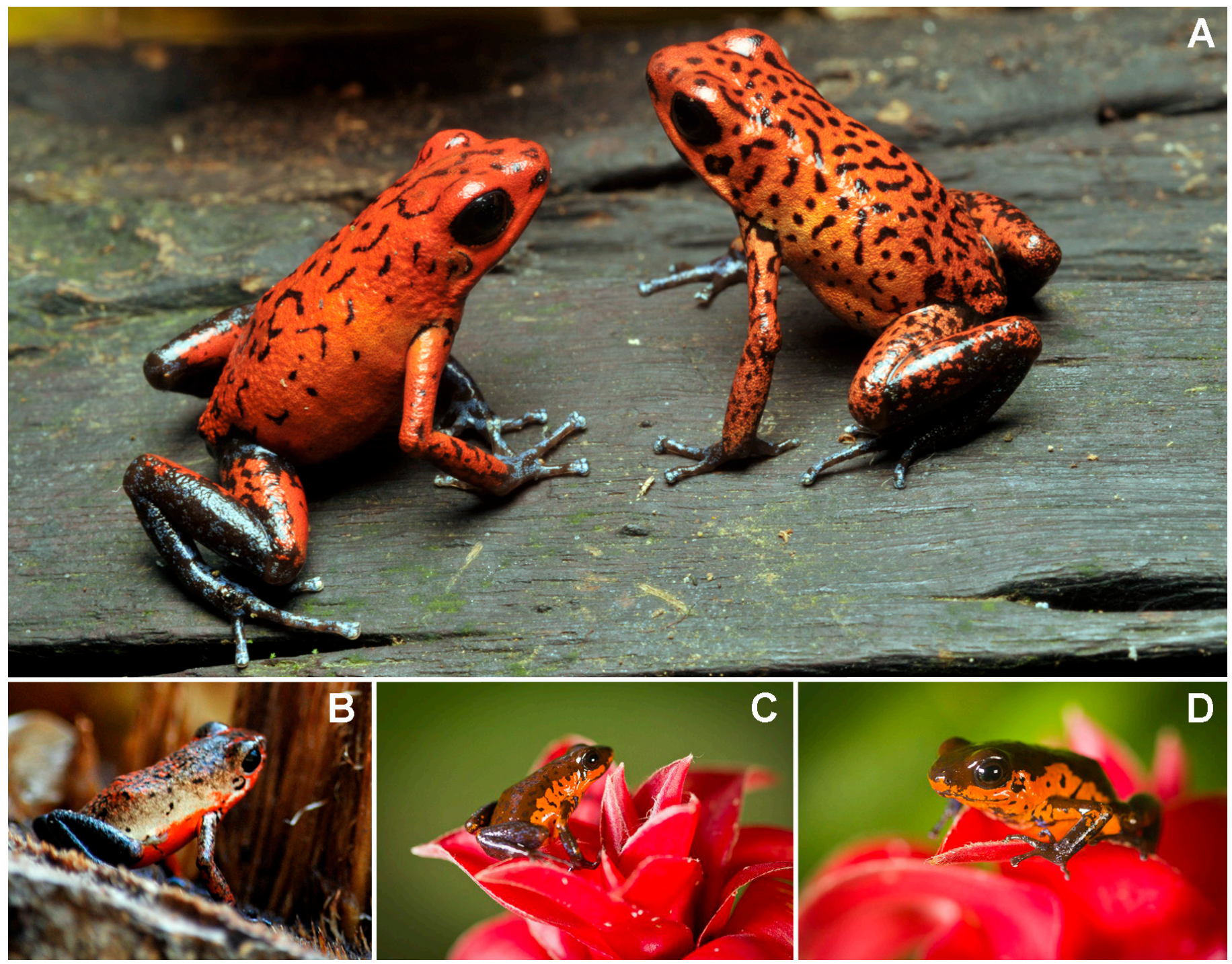

Fig. 2. Strawberry Poison Frogs (Oophaga pumilio) from the vicinity of Matina, Limón Province, Costa Rica; these are representatives of the western clade (see text). (A) Typically colored morphs; photograph by C. Barrio-Amorós. (B) An aberrant color pattern; photograph by R. Barrantes. (C-D) A somewhat similar aberrant pattern morph; photographs by B. Hovland.

gists working at the station. The animal was released after the photo session. Unfortunately, digital photo technology at the time was somewhat primitive, and the only surviving photo is presented herein. The frog was mostly royal blue with numerous irregular dorsal black spots (decreasing in size laterally and disappearing entirely on the lower flanks) and a black reticulum on the hind limbs. What appears to be a white labial stripe might be an artifact attributable to the camera flash. The most similar color pattern illustrated in van der Lingen and van der Lingen (2012) is from the region near Tierra Oscura and Aguacate in continental Bocas del Toro Province, Panama.

\section{Matina}

Frogs from the vicinity of Matina, Limon Province, Costa Rica, are representatives of the western clade and are somewhat variable in coloration. Most, however, are predominately red or orange (plain or with black spots or reticulations), with black and blue marbling on the limbs (Fig. 2A). Herein we describe two aberrant individuals from the vicinity of Matina (the exact localities are omitted in an effort to deter illegal collection).

The middorsal area and forelimbs of a calling male photographed by R. Barrantes (Fig. 2B) were reddish orange and mottled with black, the sides were tan to pale brown and largely immaculate, and the lower flanks and venter were orange. The hindlimbs and hands appear to be black. The individual was among a considerable number of more typically colored red frogs. Similarly, B. Hovland encountered the other individual (Figs. 2C-D), of unknown sex, among a number of typically colored red frogs (like those in Fig. 2A). The dorsum was dark brown with inconspicuous black small spots; the lips, flanks, and venter were intense orange with intrusions of the dorsal ground color; arms were orange with dark brown large spots, but forearms and hindlimbs were dark brown to black and blue marbling. The iris was dark 
brown, whereas those of the other morphs illustrated herein were very dark brown to black.

Although somewhat similar in appearance, these two frogs were not likely to have been closely related (although the similarity in patterns does suggest those the associated genes are present in the population). The collection sites were separated by several kilometers and both individuals were in populations comprised mostly of typically colored frogs. No similar pattern has been described from anywhere within the entire range of the species.

\section{Literature Cited}

Frost, D.R. 2016. Amphibian Species of the World: An Online Reference. Version 6.0. American Museum of Natural History, New York (http://research.amnh. org/vz/herpetology/amphibia/).

Guyer, C. and M.A. Donnelly. 2005. Amphibians and Reptiles of La Selva, Costa Rica, and the Caribbean Slope: A Comprehensive Guide. University of California Press, Berkeley.

Hagemann, S. and H. Pröhl. 2007. Mitochondrial paraphyly in a polymorphic poison frog species (Dendrobatidae: D. pumilio). Molecular Phylogenetics and Evolution 45: 740-747.

Lötters, S., K.-H. Jungfer, F.W. Henkel, and W. Schmidt. 2007. Poison Frogs. Biology, Species \& Captive Care. Edition Chimaira, Frankfurt am Main, Germany.

Savage, J.M. 2002. The Amphibians and Reptiles of Costa Rica. A Herpetofauna between Two Continents, between Two Seas. University of Chicago Press, Chicago, Illinois.

van der Lingen, C. and W. van der Lingen. 2012. The Most Complete Oophaga pumilio Morph Guide: 102 Different Color Forms/Locations. Edition Chimaira, Frankfurt am Main, Germany.

Walsh, J.G. 1994. Jewels of the Rainforest. Poison Frogs of the Family Dendrobatidae. TFH Publications, Inc., Neptune City, New Jersey. 